\title{
Kompetence: Hvad, hvorfor, hvordan?
}

\author{
Anmeldelse af Birgitte Madelung \\ Knud Illeris: \\ Kompetence: Hvad, hvorfor, hoordan? \\ 1. udgave 2011. \\ Samfundslitteratur. \\ 170 sider.
}

Begrebet 'kompetence' anvendes efterhånden i mange kontekster og med det fælles udgangspunkt, at det handler om 'at kunne noget'. Samtidigt er det også et begreb, der kontinuerligt debatteres, da der ingen tydelig enighed er om definitionen af begrebet. 'At have kompetence til' har tidligere mere entydigt betydet at kunne bedømme og træffe beslutninger på andres og egnes vegne. I løbet af de sidste årtier har begrebet indtaget nye betydninger og er tæt knyttet til uddannelse og undervisning. Samtidig er begrebet også blevet en del af den politiske dagsorden, og det kan efterhånden forekomme lidt slidt, da det er et nemt begreb at hente ned fra hylden 'at alle skal have flere kompetencer'. Men det afholder heldigvis ikke kompetente forskere $\mathrm{i}$ at undersøge og arbejde med begrebet, og den seneste, som giver sit bud, er Knud Illeris, der stiller spørgsmålene: Hvad, hvorfor og hvordan?

Det er tre relevante spørgsmål, som vi også kan stille os selv i universitære sammenhænge. Siden 2006 har vi arbejdet ud fra Kvalifikationsrammen, som beskriver de videregående uddannelsers læringsudbytte. Læringsudbyttet opdeles i tre overordnende kategorier: Viden, færdigheder og kompetencer. Fokusset på læringsudbyttet ses tydeligt $\mathrm{i}$ formuleringen af studieordninger og fagbeskrivelser, hvor der er flyttet fokus fra pensum til målbeskrivelser, og derfor er det også relevant at kigge nærmere på, hvad disse kategorier indeholder, og hvordan der kan arbejdes med dem. Her kommer Knud Illeris' bog som et godt bidrag til den ofte lidt mindre konkrete, men ikke mindre væsentlige kategori af kompetencer.

Illeris har naturligvis sin definition på begrebet: Kompetence er "noget som alle udvikler i forhold til, hvad de beskæftiger sig med og ikke mindst, hvad de går op i" (p. 37). Det handler først og fremmest om at kunne handle "i relation til bestemte kendte, ukendte og uforudsigelige situationer" (p. 33). Det er altså egenskaber, man har tilegnet sig, som er forudsætninger for, at man kan handle i nye sammenhænge. Det leder tanken hen på Donald Schöns begreb 'indeterminate zones of practice', og Illeris sætter netop også fokus på handlingsorientering, som kompetencebegrebets væsentligste element. 
Fokus på handlingsorientering og praksiserfaring sætter nye perspektiver på udviklingen af undervisningen, og bogens væsentligste bidrag kommer i kapitel 7, hvor Illeris formulerer 'Kompetenceformlen'. Her udpeges tre nøgleord - 'engagement', 'praksis' og 'refleksion' - som udgør grundformlen i kompetenceudvikling. Illeris erkender selv, at den kan forekomme upræcis, men den ganske simple model beskriver meget fint igangsættelsen af læreprocessen, den praksis der understøtter kompetencetilegnelsen og endelig de afsluttende processer, der skaber overblik over processen og opnåelsen af de mål, der er blevet sat. Faktisk fremlægger Illeris to modeller i erkendelse af, at de ikke-erhvervsrettede uddannelser ikke har et praksisfelt, og praksis derfor er udskiftet med 'problem'. Illeris understreger, at det ikke er uden problemer, idet visse praksiserfaringer ikke kan erstattes.

Det er en ganske enkel model, Illeris bringer på banen, men den er ganske brugbar, og kan fint sidde som en lille huskeseddel på opslagstavlen inden undervisningen forberedes. Vi lærer ikke, uden vi er engagerede og har accepteret præmisserne, vi lærer ved den direkte handling, og vi skal altid forholde hos til vores handling gennem refleksion herunder ikke mindst feedback. Som undervisere er vi med til at finde engagementet, tydeliggøre præmisserne, skabe grundlaget for handlinger til at øve sig på og ikke mindst give feedback og understøtte den studerendes refleksion over handlinger og det lærte.

Illeris arbejder med et bredt kompetencebegreb og introducerer sin version af en kompetenceblomst. Den fremstår ikke som et konkret værktøj men er en visualisering af de elementer, der udgør en bred handlingskompetence eller det at kunne handle i bestemte situationer. I kapitel 2-5 gennemgår Illeris den række af kompetenceelementer, han medtager, og som han opdeler i generelle og udvidede kompetencer. Under de generelle finder vi elementer så som kundskaber og selvstændighed og af udvidede kompetencer nævnes bl.a. empati og modstandspotentiale. En sådan liste kan altid debatteres, men den giver et solidt billede af 'alt det andet', som vi implicit ofte forventer at de studerende kan.

Illeris lægger yderligere de elementer på, at vi hhv. har dispositioner 'for' og potentialer 'til' noget. Dispositioner har, ifølge Illeris, deres forankring i generne, men udvikles i individets kontekst. Potentialer til noget handler derimod om de forudsætninger, vi har udviklet for at tage vare på bestemte handlinger og opgaver. Set fra et undervisningssynspunkt er potentiale elementet interessant, fordi det sætter fokus på, hvordan vi understøtter udviklingen af handlingskompetence i vores arbejde med de studerende. Og netop, hvordan kompetencer udvikles, er fokus for kapitlerne 6-8. For dem, der har læst Illeris' Lxring (2006), er det genkendelsen som bidrager til læsningen af kapitel 6, og nye læsere får et behageligt overblik. Hovedkonklusionen er, ikke overraskende, at udviklingen af kompetencer forudsættes af læringens tre dimensioner: Indhold, motivation og samspil. Læringens tre dimensioner kan 
ifølge Illeris ikke adskilles, men han har altid fremhævet motivation som det afgørende parameter og understreger det her ved at citere Lennart Parknäs, som i 1976 opsummerede sit arbejde i en enkelt linje: "Det drejer sig ikke om at skabe motivation, men om at finde den." (p. 92).

Den største udfordring for en uddannelsesinstitution er Illeris' konklusion, at kompetencer ikke kan måles. Fordi de er konkret handlingsorienterede, vil en eksamen aldrig kunne verificere den buket af kompetencer, mange handlinger vil kræve. Vi kommer ikke væk fra eksamen som evalueringsform og blåstempling, men da vi også debatterer og udvikler undervisningen, skal vi også fortsat forholde os til, hvad eksamen kan og skal. Og det vil være ganske udbytterigt, hvis vi også accepterer, at ikke al læring kan og skal måles. Det er processen (etablering af engagement, praksis og feedback), som er vores fremmeste opgave som undervisere, og dette bør også åbne op for nye og læringsunderstøttende evalueringsformer.

Illeris' bog om kompetencer er et solidt bidrag til både debatten om kompetencer og til forståelsen af, hvordan vi lærer. Den er nem at gå til, og bogens tre afsnit kan læses separat. Den kan anbefales som oplæg til debat og inspiration, når undervisningen planlægges rundt omkring på de mange uddannelser, og den kan være med til at kvalificere brugen af kvalifikationsrammen, så kompetencer ikke bare bliver et element, der indskrives i studieordningerne, uden at det reelt bliver materialiseret. Læs den gerne sammen med dine kollegaer, for kompetencer udvikles ikke i enkelte fag, men bredt henover et uddannelsesforløb.

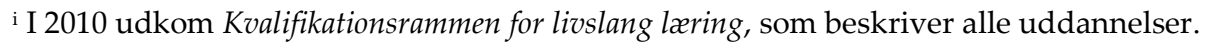

